\title{
GIS-Based Multi-Criteria Wind Farm Site Selection Methodology
}

It is prevalent that by 2050, the global energy demand would increase by $50 \%$ to the current demand. The projected demand for electricity in Saudi Arabia is expected to exceed 120 GW/year by 2032. The Saudi government has set a goal of generating 9.5 GW of wind energy by 2023. In this study, firstly, a spatial interpolation technique is used to build a first accurate wind map of the entire country, then a GIS-based multicriteria decision-making model is developed to select suitable wind farm sites considering various ecological, environmental and socio-economic criteria. All the identified criteria are given equal weightage in the model. Therefore, with noncompliance with even a single criterion, the associated complete area is considered unsuitable. As a case study, this model is independently applied to four regions covering the entire of Saudi Arabia. In the northern region, three wind farm sites are identified. The central area has a more suitable area compared to other regions mainly due to good wind resources and road and grid connectivity. The suitable sites in the eastern region are located between Dammam and Hafr AlBatin city. The southern region has a scarcest suitable area for wind power exploitation located near the province of Madinah.

Keywords: GIS; Wind map; Multi-criteria decision making; Wind energy; Wind Farm; Site suitability analysis.

\section{INTRODUCTION}

Energy is vital for the growth of any country. Most of the energy is utilized by the industrial sector followed by the transportation, commercial, and residential sectors. It is stated that by 2050 , the global energy demand would increase by $50 \%$ to the current demand [1]. Almost all of the energy consumption is provided by the burning of fossil fuels in the last century. This persistent burning of fossil fuels is the cause of growing environmental concerns and resulting in the depletion of fossil fuels. These concerns are the cause of exploring various alternative clean, renewable, and environmentally friendly resources of energy [2-4. Currently, wind energy is one of the most emerging renewable, sustainable, and commercially accepted sources of energy. The cost of electricity generated from modern commercial wind turbines is currently at par with energy generated by fossil fuel plants [5]. In the year 2018, 51.3 GW of new wind energy was installed globally [6]. To fulfill the government's initiative, Saudi Vision 2030 of generating $9.5 \mathrm{GW}$ of wind energy by 2023, a 400 MW wind farm is planned in Dumat alJandal, Sakaka [7]. This wind farm is expected to be operational by the end of 2020 and would produce energy at a cost of $\$ 21.3$ per MWh. Compared to European countries, wind energy penetration in the Middle East and Saudi Arabia is in an early stage. Saudi Arabia has huge empty plain land and good wind resource,

Received: May 2020, Accepted: July 2020

Correspondence to: Dr. M.A. Baseer, Department of Mechanical \& Manufacturing Engineering Technology, Jubail Industrial College, Jubail, Saudi Arabia,

E-mail: baseer_m@jic.edu.sa

doi: 10.5937/fme2004855R

(C) Faculty of Mechanical Engineering, Belgrade. All rights reserved suitable for the realization of wind farms to attain greater wind power penetration locally and globally.

Precise wind farm siting is the first and major challenge in profitable wind turbines installations. The site location should satisfy all ecological, environmental, and socioeconomic constraints and policies in addition to wind energy resources. The geographic information system, GIS is an effective tool for site suitability analysis when integrated with long-term accurate data of various criteria involved in decision making. The multi-criteria decision making (MCDM) analysis provides a tool for structuring, designing, evaluating, and prioritizing alternative decisions [8]. The use of GIS-based MCDM analysis for the planning of wind farms gained importance in the early 2000s [9]. The GIS-based, Multi-criteria-decision making approach was applied to wind farm siting in Lancashire, UK in 2001 [10]. Two methods were used for the analysis. The first method used equal weightage or equal importance to all the criteria or layers identified for the region. The second method used weightage based on the importance of each layer or criteria pertaining to expert advice and prevalent in the literature [10].

Krewitt and Nitsch (2003), addressed the effects of wind farms on the local ecosystem and natural scenery in coastal regions of Germany. Criteria like landscape conservation areas, special bird protection areas, or areas with high visual sensitivity were considered in identifying suitable locations for wind farms. The study suggested that even under strict nature's conservation constraints there is still a large potential for on-shore wind energy development in Germany [11]. In Denmark, near the Baltic Sea region, a spatial planning tool was developed for efficient wind energy planning. This tool used multi-criteria evaluations for analyzing the 
complex trade-offs between alternatives with different environmental and socioeconomic impacts [12].

The availability of long-term historical data of the criteria parameters in conjugation with efficient latest GIS tools has made it possible to make precise MCDM wind farm siting analysis. Therefore, the following state -of-the-art studies are supposed to be more accurate. In Turkey, 55 coastal regions were analyzed by the multicriteria site selection process. Wind Atlas Analysis and Application Program (WAsP) was used to conduct statistical analysis to identify the most promising offshore wind farm deployment locations. According to the pre-processing step of the framework, only five coastlines were found to be the most suitable locations for offshore wind farm development [13]. In China, ecological, socioeconomic, and social environment criteria were selected and an ordered weighted average was applied to evaluate the suitability of the development of wind energy resources [14]. The study found that suitable sites were distributed in the Huludao, Jinzhou and Yingkou beach areas and shoreline of the Bohai Sea, Fuxin and Chaoyang in the Northwest Area, Dandong alpine region in the eastern Shenyang, Tieling, and Anshan in central plain areas.

Azad et al. (2019) studied three sites, Hamilton Island, Proserpine, and South Johnstone to identify the most suitable one for wind turbine installation. The wind energy potential was determined by using Weibull parameters obtained by the method of moments, empirical method, and power density method. The accuracy of the results was analyzed using a statistical test tool. Finally, Hamilton Island site was selected as the best for the proposed wind turbine specification [15]. A wind farm planning tool was developed in Greece at the regional level. All the criteria discussed earlier were addressed but the criteria of proximity to the electricity grid were not considered. It was found that $12 \%$ of the study area is suitable for wind farms installations [16].

The single most important task in GIS-based, multicriteria analysis is the proper and comprehensive selection of economic, planning, and ecological criteria applicable to the study area based on the national policies. In this study, a comprehensive set of ecological, environmental, and socioeconomic constraints and policies are identified without reservations, and accurate data is procured for the entire country. The novelty and the uniqueness of the present work is development of a first accurate wind map was based on longterm historical wind data for 39 years from 46 weather stations country-wide and this study does not ignore any input criteria to identify the best area for wind farms development. To our understanding, based on the literature review, the earlier authors have ignored a few relevant criteria, mainly due to the unavailability of accurate long-term data of that criterion, as shown in Table 1. Moreover, no study has considered the criteria of minimum suitable continuous area for ease of wind farm layout planning. The wind resource assessment is conducted at all of these locations and mean wind speed is determined by Weibull analysis and the novel wind speed map is constructed using spatial interpolation method, Inverse distance weighted (IDW). All the identified criteria are given equal weightage, therefore, with noncompliance of even a single criterion condition the complete associated area is considered unsuitable. An innovative wind farm site suitability map is developed for four areas covering the entire country. This study will assist in achieving the initial goal of the government to produce $9.5 \mathrm{GW}$ of wind energy and will also help in developing comprehensive national wind energy-related policies that are currently not specifically defined for the region.

\section{DESCRIPTION OF THE STUDY AREA}

\subsection{Study area}

In this analysis, entire Saudi Arabia is considered a study area. Saudi Arabia is located in the southwestern corner of Asia. It is bordered by Kuwait, Iraq, and Jordan in the north; Oman and Yemen in the South; United Arab Emirates, Qatar, and Arabian Gulf in the East; and the Red Sea in the West. The total area of Saudi Arabia, (the thirteenth largest country in the world and largest in the Middle East), is 2.15 million $\mathrm{km}^{2}$ [17].

In 1991, Saudi Arabia was divided into (13) administrative provinces as shown in Figure 1, each with various governorates. The settlements are linked administratively to these governorates [17]. In this study, four areas are selected as shown in Figure 2 to find suitable sites for wind farms development in each. The southern area consists of Madinah, Makkah, Bahah, Asir, Jizan, and Najran provinces. The northern area consists of Tabuk, Al Jawf, and Al hudud ash Shamaliyah provinces. The central area consists of Hail, Al Quassim, and Riyad provinces. Finally, the eastern area consists of only one province, Ash Sharqiyah. This province also includes the Empty Quarter composed of the world's largest unpopulated sand dunes and lava fields and occupies an estimated area of $640,000 \mathrm{~km}^{2}$ [18].

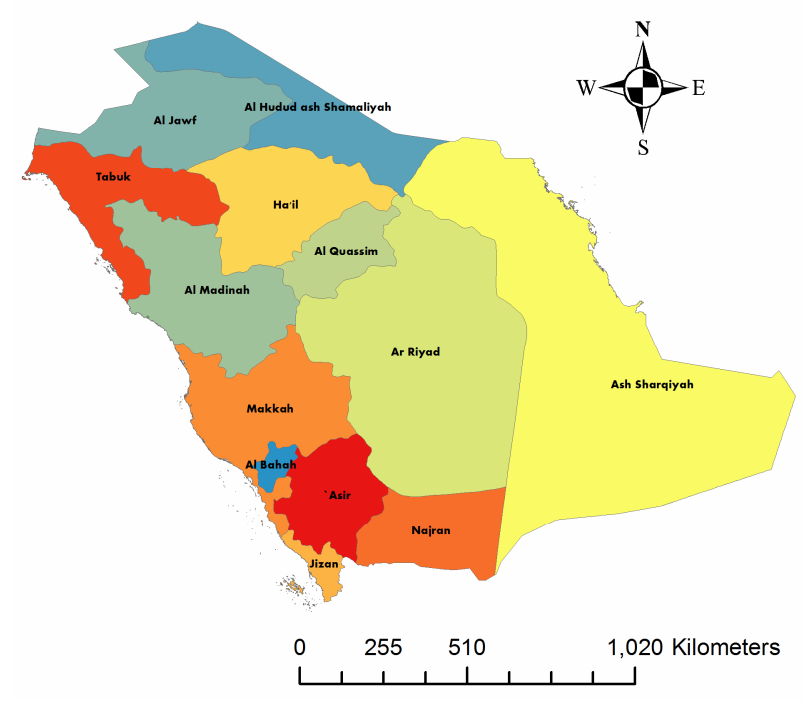

Figure 1. The thirteen provinces of Saudi Arabia

Saudi Arabia has huge geographically diverse land with varying climatic conditions. Most of the regions, like in the eastern province, are generally hot in summer and cold in winter with moderate rainfall. In general, the climate in the western and southern regions is moderate. [17]. 
Table 1. Selection of restriction criteria for wind farm site selection studies worldwide.

\begin{tabular}{|c|c|c|c|c|c|c|c|c|c|c|}
\hline \multirow{2}{*}{$\begin{array}{l}\text { Study area/ } \\
\text { Study } \\
\text { Criteria }\end{array}$} & \multicolumn{2}{|c|}{ Economic } & \multicolumn{3}{|c|}{ Planning } & \multicolumn{3}{|c|}{ Ecological } & Geographical & \\
\hline & $\begin{array}{l}\text { Wind } \\
\text { speed } \\
\text { /density }\end{array}$ & $\begin{array}{l}\text { Proximity } \\
\text { to the } \\
\text { electricity } \\
\text { grid, m }\end{array}$ & $\begin{array}{l}\text { Safe } \\
\text { distance } \\
\text { from } \\
\text { aerodromes, } \\
\text { m }\end{array}$ & $\begin{array}{l}\text { Distance from } \\
\text { roads/highwa } \\
\text { ys, m }\end{array}$ & $\begin{array}{l}\text { Distance } \\
\text { from } \\
\text { settlements } \\
\text { m }\end{array}$ & \begin{tabular}{|l|} 
Distance \\
from birding \\
locations \\
and flying \\
paths, m
\end{tabular} & $\begin{array}{l}\text { Distance } \\
\text { from parks, } \\
\text { forests and } \\
\text { public } \\
\text { places, m }\end{array}$ & $\begin{array}{l}\text { Distance } \\
\text { from } \\
\text { lakes, } \\
\text { rivers and } \\
\text { springs, m }\end{array}$ & $\begin{array}{l}\text { Terrain } \\
\text { slope, \% }\end{array}$ & \\
\hline Denmark & $\begin{array}{l}250-650 \\
W / m^{2}\end{array}$ & $x$ & $5000-7500$ & $x$ & $500-1500$ & $x$ & $300-800$ & $150-650$ & $x$ & {$[12]$} \\
\hline Germany & $\begin{array}{lr}>4 & \mathrm{~m} / \mathrm{s} \\
10 & \mathrm{at} \\
\mathrm{AGL}) & \mathrm{m}\end{array}$ & $x$ & $x$ & $>500$ & $>500$ & $x$ & $>500$ & $x$ & $x$ & {$[11]$} \\
\hline Greece & $5-7.5 \mathrm{~m} / \mathrm{s}$ & $x$ & 3000 & $5000-200$ & 1500 & $x$ & 1000 & 1000 & $>25 \%$ & {$[16]$} \\
\hline Spain & $<4.5 \mathrm{~m} / \mathrm{s}$ & $>100$ & 2500 & $>100$ & $>550$ & $x$ & $>200$ & $<50 \mathrm{~m}$ & $>30 \%$ & [47] \\
\hline Sweden & $\begin{array}{l}\text { Turbine } \\
\text { output }\end{array}$ & $>200$ & 2500 & $>200$ & $>500$ & $x$ & $x$ & $>100$ & $>15^{0}$ & {$[23]$} \\
\hline Turkey & $\begin{array}{l}200-400 \\
W / m^{2}\end{array}$ & $x$ & $3000-6000$ & $x$ & $1000-2000$ & $>500$ & $3000-6000$ & $2500-5000$ & $x$ & [29] \\
\hline UK & $>5 \mathrm{~m} / \mathrm{s}$ & $<10000$ & $x$ & $<10000$ & $>2000$ & $x$ & $>500$ & $>400$ & $>10 \%$ & [10] \\
\hline USA & $x$ & $\begin{array}{l}\text { Cost } \\
\text { analysis }\end{array}$ & $x$ & $<5000$ & $>2000$ & \begin{tabular}{|l|} 
Away from \\
selected \\
IBA's
\end{tabular} & $x$ & $>3000$ & $>10 \%$ & {$[21]$} \\
\hline Vietnam & $\begin{array}{l}\text { Turbine } \\
\text { output }\end{array}$ & $x$ & 2500 & $>100$ & $>2000$ & $x$ & $>500$ & $>400$ & $x$ & [30] \\
\hline
\end{tabular}

Table 2. The wind station names, location (latitude and longitude), altitude, and hourly average wind speed.

\begin{tabular}{|c|c|c|c|c|c|}
\hline S.No & Wind station & $\begin{array}{l}\text { Latitude } \\
(\mathrm{N})\end{array}$ & $\begin{array}{l}\text { Longitude } \\
\text { (E) }\end{array}$ & $\begin{array}{l}\text { Altitude } \\
(\mathrm{m})\end{array}$ & $\begin{array}{c}\text { Av. WS at } 50 \mathrm{~m} \text { AGL } \\
(\mathrm{m} / \mathrm{s})\end{array}$ \\
\hline 1 & Abha & 18.2 & 42.7 & 2093 & 3.74 \\
\hline 2 & Ad-Dawadimi & 24.5 & 44.4 & 900 & 6.47 \\
\hline 3 & Afif & 24 & 43.125 & 984 & 6.5 \\
\hline 4 & Al Ahsa & 25.5 & 49.375 & 178 & 5.81 \\
\hline 5 & Al Baha & 20 & 41.25 & 1652 & 4 \\
\hline 6 & Al Hawiyah & 29 & 38.75 & 888 & 5.57 \\
\hline 7 & Al Jawf & 29.8 & 39.9 & 753 & 5.68 \\
\hline 8 & Al Jubail & 27 & 49.375 & 3 & 5.77 \\
\hline 9 & Al Khafji & 28.5 & 48.125 & 31 & 6.18 \\
\hline 10 & Al Kharj & 24 & 47.5 & 512 & 5.59 \\
\hline 11 & Al Lith & 20 & 40.625 & - & 3.67 \\
\hline 12 & Al Qunfudah & 19 & 41.25 & - & 3.85 \\
\hline 13 & Ar Rass & 26 & 43.75 & 779 & 5.82 \\
\hline 14 & Arar & 31 & 41.25 & 549 & 5.43 \\
\hline 15 & Az Zulfi & 26.5 & 45 & 623 & 6.1 \\
\hline 16 & Bisha & 20 & 42.5 & 1162 & 5.8 \\
\hline 17 & Damat Al Jamdal4 & 30 & 40 & - & 5.59 \\
\hline 18 & Damat Al Jandal1 & 29.5 & 39.375 & - & 5.6 \\
\hline 19 & Damat Al Jandal2 & 29 & 40 & - & 5.59 \\
\hline 20 & Damat Al Jandal3 & 29.5 & 38.75 & - & 5.5 \\
\hline 21 & Dariyah & 24.5 & 43.125 & 949 & 6.48 \\
\hline 22 & Dhahran & 26.5 & 50 & 17 & 5.82 \\
\hline 23 & Gassim & 26.5 & 43.75 & 648 & 5.76 \\
\hline 24 & Guriat & 31.5 & 37.5 & 504 & 5.73 \\
\hline 25 & Hafr AlBatin & 28.5 & 46.25 & 358 & 6.15 \\
\hline 26 & Hail & 27.5 & 41.875 & 1002 & 5.85 \\
\hline 27 & Jeddah & 21.5 & 39.375 & 17 & 5.24 \\
\hline
\end{tabular}




\begin{tabular}{|l|l|c|c|c|c|}
\hline S.No & \multicolumn{1}{|c|}{ Wind station } & $\begin{array}{c}\text { Latitude } \\
(\mathrm{N})\end{array}$ & $\begin{array}{c}\text { Longitude } \\
(\mathrm{E})\end{array}$ & $\begin{array}{c}\text { Altitude } \\
(\mathrm{m})\end{array}$ & $\begin{array}{c}\text { Av. WS at 50 m AGL } \\
(\mathrm{m} / \mathrm{s})\end{array}$ \\
\hline 28 & Khamis Mushait & 18.5 & 43.125 & 2056 & 5.39 \\
\hline 29 & Madinah & 24.5 & 39.75 & 636 & 5.55 \\
\hline 30 & Makkah & 21.5 & 40 & 240 & 4.99 \\
\hline 31 & Mudaylif & 19.5 & 41.25 & 53 & 3.73 \\
\hline 32 & Nejran & 17.5 & 44.375 & 1212 & 4.95 \\
\hline 33 & Rabigh & 23 & 39.375 & 382 & 4.64 \\
\hline 34 & Rafha & 29.5 & 43.75 & 444 & 5.78 \\
\hline 35 & Riyadh & 24.5 & 46.875 & 620 & 5.72 \\
\hline 36 & Sabya & 17 & 42.5 & 295 & 3.78 \\
\hline 37 & Safwah & 26.5 & 50 & 53 & 5.82 \\
\hline 38 & Sharourah & 17.5 & 46.875 & 725 & 5.82 \\
\hline 39 & Sulayel & 20.5 & 45.625 & 614 & 5.89 \\
\hline 40 & Tabuk & 28.5 & 36.875 & 768 & 5.45 \\
\hline 41 & Taif & 21.5 & 46.875 & 453 & 5.45 \\
\hline 42 & Turaif & 31.5 & 38.75 & 852 & 6.08 \\
\hline 43 & Ummluj & 25 & 37.5 & 411 & 5.22 \\
\hline 44 & Unayzah & 26 & 43.75 & 724 & 5.82 \\
\hline 45 & Wejh & 26.5 & 36.25 & 24 & 5.99 \\
\hline 46 & Yanbo & 24 & 38.125 & 10 & 5.08 \\
\hline & & & & & \\
\hline
\end{tabular}

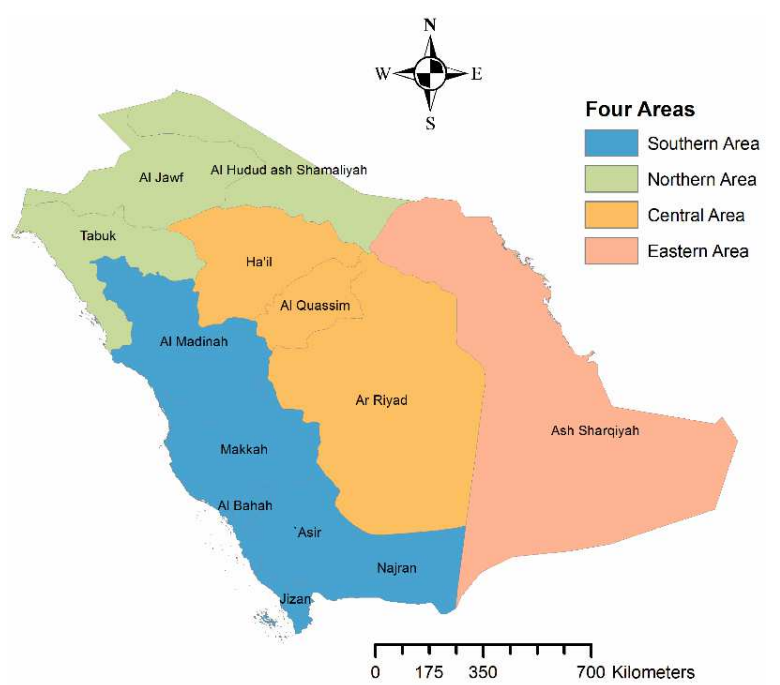

Figure 2. The four selected areas of Saudi Arabia

The demand for energy and desalinated water in Saudi Arabia in increasing rapidly due to growth in population and fast industrialization. The population increased by more than $500 \%$ in the last four and a half decades [17], during the same period, the number of industries increased by around 35 times [19]. By 2030, the projected demand for energy is expected to exceed $120 \mathrm{GW} /$ year [20].

\section{DESCRIPTION OF THE IDENTIFIED WIND FARM SITE SELECTION CRITERIA}

All the criteria that have any impact on the site selection were carefully identified from the literature. The identified criteria and description are presented below.

\subsection{Wind Speed}

The wind resource is the foremost criterion in all wind farm site selection studies reviewed [21-23]. In this study, the long-term historical hourly time step wind data from 1980 to 2019 was obtained for 46 stations throughout the country [24] as shown in Figure 3. The location of the stations, average wind speed at a height of $50 \mathrm{~m}$, and the altitude of stations are presented in Table 2 below.

The mean wind speed data in this study is interpolated to $50 \mathrm{~m}$ from the anemometer height of 10 m AGL by using one-seventh power law also known as Hellmann's power law [25,26].

$$
V_{2}=V_{1}\left(\frac{Z_{2}}{Z_{1}}\right)^{n}
$$

where $V_{2}$ is the average wind speed to be found at height $Z_{2}$, when the average wind speed, $V_{1}$ at height $Z_{1}$ is available, and ' $n$ ' is the wind shear coefficient, dependent on the geographic features of the site terrain. This value is assumed to be $1 / 7$ for open land with fewer trees and bushes. [27, 28].

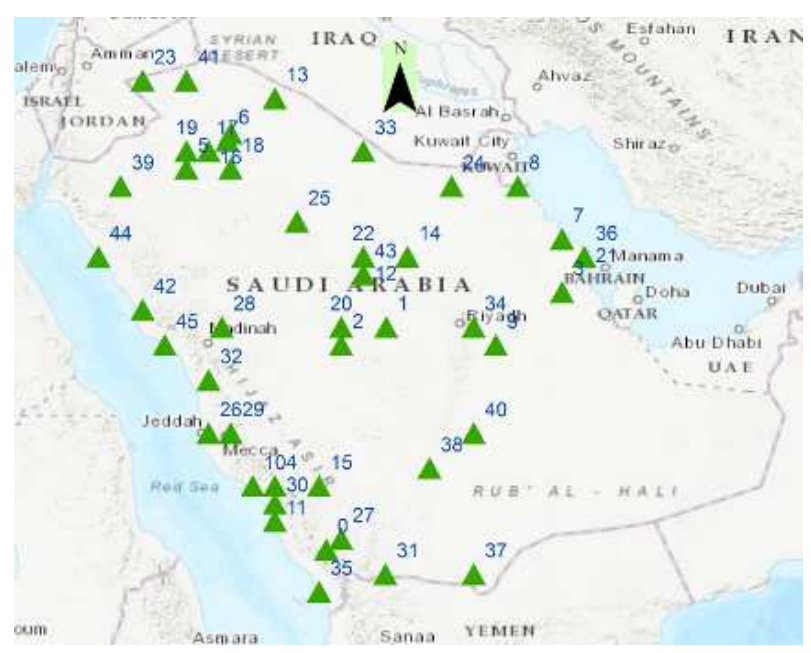




\begin{tabular}{|l|l|l|l|l|l|}
\hline 1. & Abha & 17. & Damat Al Jamdal4 & 33. & Rabigh \\
\hline 2. & $\begin{array}{l}\text { Ad- } \\
\text { Dawadimi }\end{array}$ & 18. & Damat Al Jandal1 & 34. & Rafha \\
\hline 3. & Afif & 19. & Damat Al Jandal2 & 35. & Riyadh \\
\hline 4. & Al Ahsa & 20. & Damat Al Jandal3 & 36. & Sabya \\
\hline 5. & Al Baha & 21. & Dariyah & 37. & Safwah \\
\hline 6. & Al Hawiyah & 22. & Dhahran & 38. & Sharourah \\
\hline 7. & Al Jawf & 23. & Gassim & 39. & Sulayel \\
\hline 8. & Al Jubail & 24. & Guriat & 40. & Tabuk \\
\hline 9. & Al Khafji & 25. & Hafr AlBatin & 41. & Taif \\
\hline 10. & Al Kharj & 26. & Hail & 42. & Turaif \\
\hline 11. & Al Lith & 27. & Jeddah & 43. & Ummluj \\
\hline 12. & Al Qunfudah & 28. & Khamis Mushait & 44. & Unayzah \\
\hline 13. & Ar Rass & 29. & Madinah & 45. & Wejh \\
\hline 14. & Arar & 30. & Makkah & 46. & Yanbo \\
\hline 15. & Az Zulfi & 31. & Mudaylif & & \\
\hline 16. & Bisha & 32. & Nejran & & \\
\hline
\end{tabular}

Figure 3. Locations of meteorological stations.

\subsection{Distance from the electricity grid}

A wind farm should be planned in proximity to the electricity grid to avoid transmission losses and cabling costs. Some studies have neglected this important criterion in their model $[12,16,29,30]$. For the current analysis, the map of the national electrical grid (Figure 4) and power stations was acquired from the Saudi Electrical Company, [31]. The existing, planned, and ongoing electrical grid lines are considered in this study.

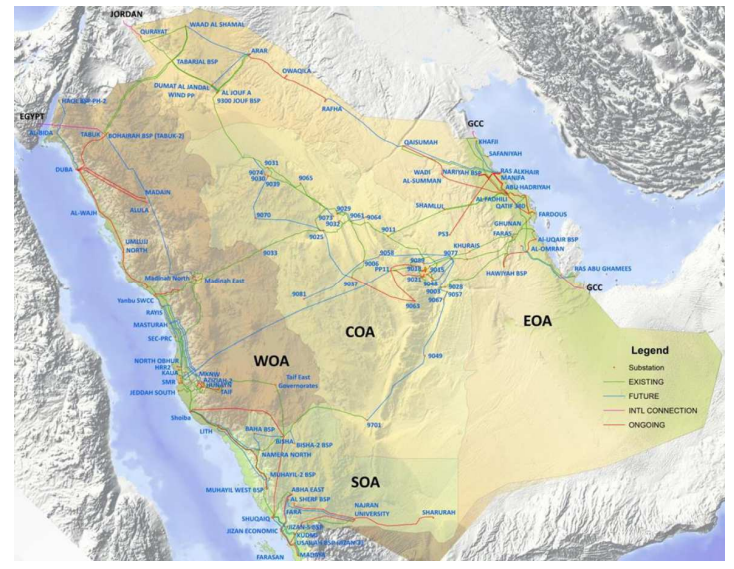

Figure 4. The electricity grid map of Saudi Arabia. (Saudi Electricity Company, 2019)

\subsection{Distance from settlements}

The minimum distance from major settlements to a prospective wind farm is a vital criterion for ecological reasons and to avoid noise and other hazards. Almost all the studies reviewed have considered this criterion. However, the prohibited buffer distances vary as shown in Table 1 [10,16,21-23,29]. This distance should also be reasonably within a specific range to serve the immediate community in an optimum manner without transmission losses [29, 12].

\subsection{Distance from roads/highways}

A prospective wind farm should be within close vicinity to a suitable approach road for heavy vehicles that carry huge commercial wind turbines and also used for maintenance work after installation. Some studies also recommend prohibitory distance $[16,23]$ which is generally not considered very important. The reviewed studies considered different distances from the road, Latinopoulos and Kechagia, 2015 [16] and Van Haaren and Fthenakis, 2011 [21] used a maximum distance of $5000 \mathrm{~m}$, Baban, and Parry, 2001 [10] used $10000 \mathrm{~m}$ and Sliz-Szkliniarz and Vogt, 2011 [22] used the buffer distance of 100 and 200 m only.

The GIS shapefiles of national highways (Figure 5) and roads (Figure 6) are procured from online libraries of Stanford University [32] and are compared with data from the ministry of transport, Saudi Arabia.

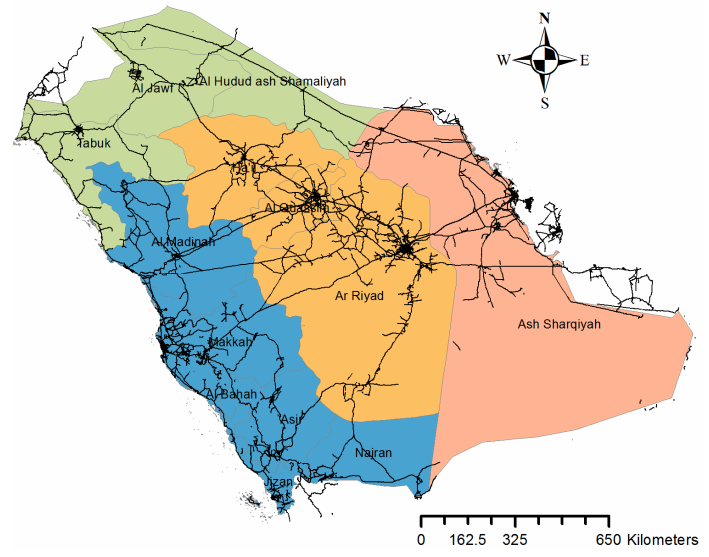

Figure 5. The Saudi Arabian highways.

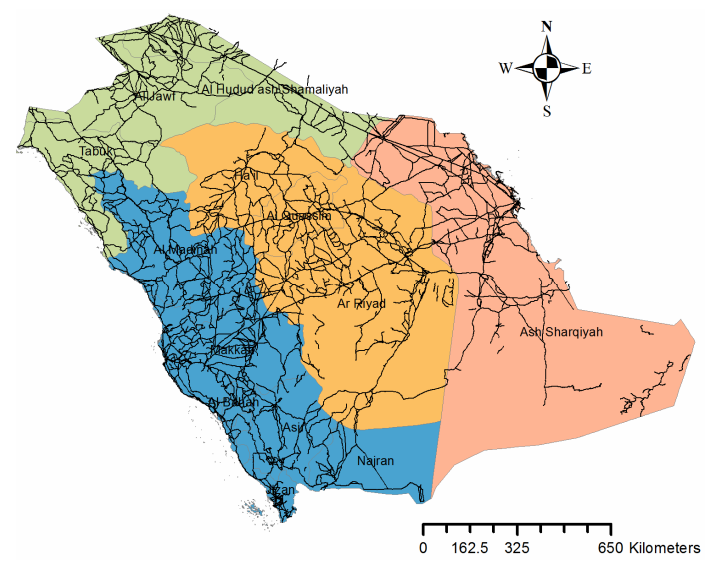

Figure 6. The Saudi Arabian roads.

\subsection{Safe distance from aerodromes}

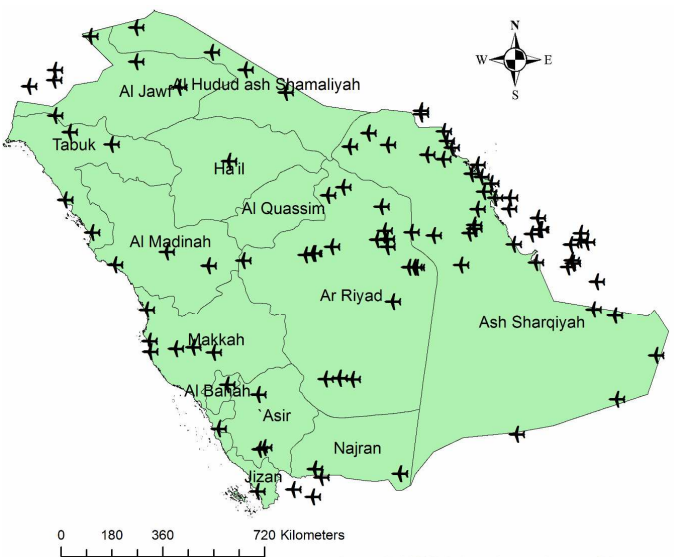

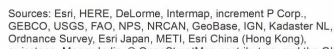

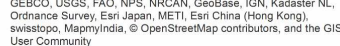

Figure 7. Aerodromes (International, domestic, cargo, and military) of Saudi Arabia. 
Wind turbines may interfere with the radar signal used by aerodromes and aircraft. Therefore, a prospective wind farm should have a safe distance from the airports (Figure 7) and communication towers. The reviewed literature presents a buffer distance of 3000 to $6000 \mathrm{~m}$ around airports [16,29].

\subsection{Distance from parks, forests, and places of tourism}

The aesthetic aspects of wind farms may conflict with public places like parks, forests, and places of tourism. The criterion of suitable distance from these places is an essential aesthetic criterion. Some studies have ignored this criterion $[21,23]$. The studies that have considered this criterion have applied different restrictions based on the local energy policies $[10,16,21,20]$.

\subsection{Impact on birds}

The migrating birds may collide with the rotating wind turbine blades, so it is recommended to plan a wind farm away from the migrating path of the birds or even away from important bird areas, IBA. Only a few studies have considered this relevant criterion [21], [29] as shown in Table 1. In the fall season, from August to October, the birds migrate to Europe from Asia and Africa and return between March and May. Saudi Arabia is a transit point for these migrating birds [33].

Out of the fifteen IBA's in the Arabian Peninsula [34] as shown in Figure 8, none are located inside Saudi Boundary and five are near national boundary. Saudi Arabia, in general, is dry land, and birds fly over mountain ranges, water bodies and natural habitats for survival. In this study, the popular birding locations are also considered (Figure 9).

Almost all the birding locations are in the eastern province and one in $\mathrm{Al}$ Qassim region. Some studies have not considered in their analysis, the acceptance criteria in terms of bird habitat may be due to noninterference with IBAs [10,30].

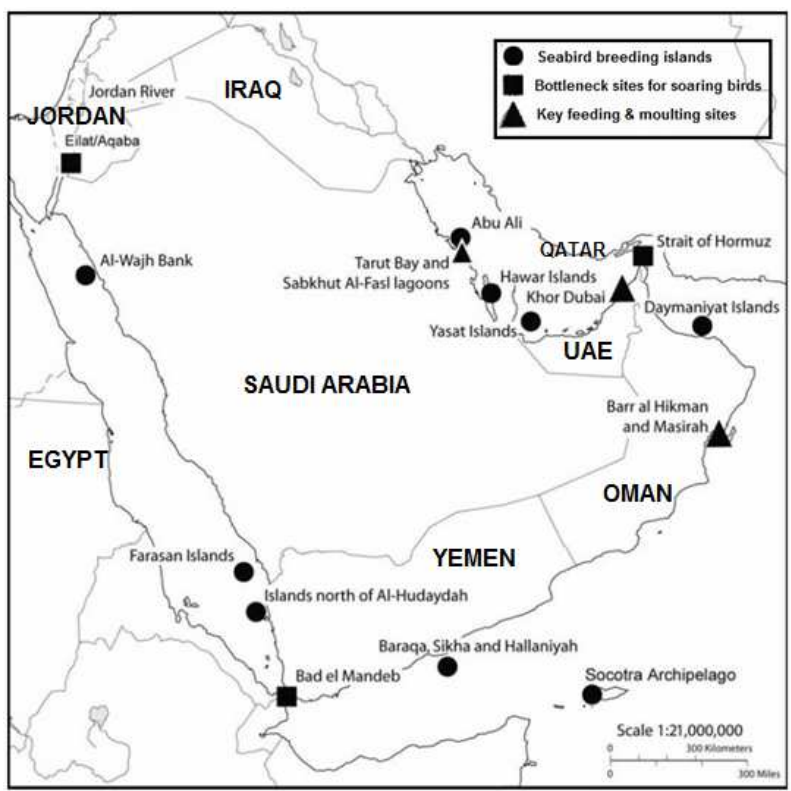

Figure 8. The Important bird areas, IBA near Saudi Arabia (Pavokovic and Mandusik, 2006).

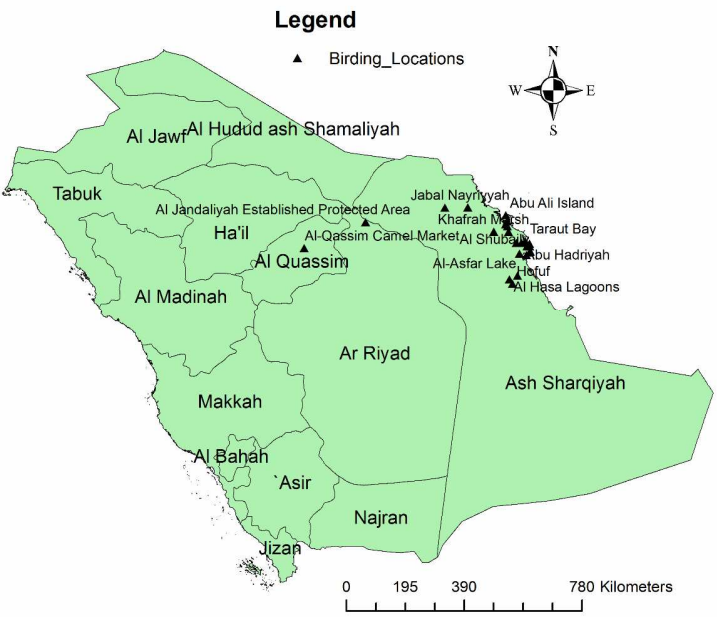

Figure 9. The birding locations in Saudi Arabia

\subsection{Distance from lakes, rivers, and springs}

Almost all the reviewed studies have considered the criteria of unsuitable buffer distance from water bodies and waterways $[10,16,29]$. In Saudi Arabia, there are very few perennial rivers. However, there are few springs, water bodies, and non-perennial rivers as shown in Figure 10.

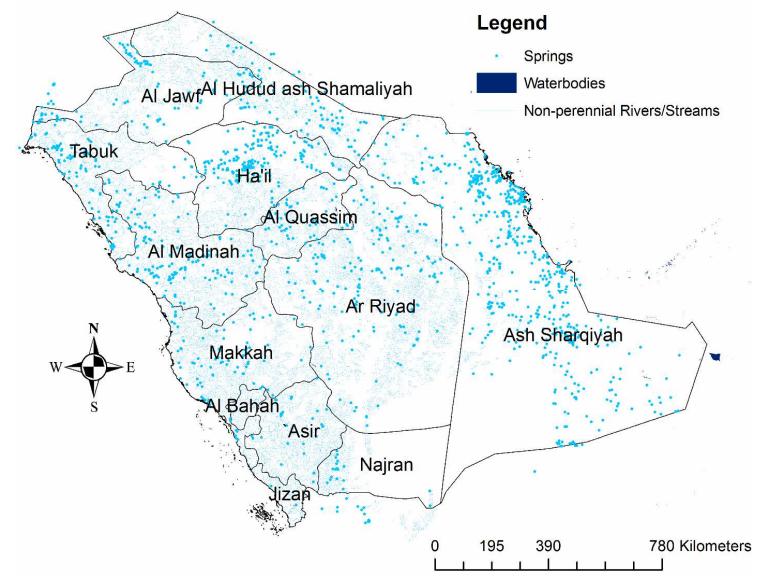

Figure 10. The waterbodies of Saudi Arabia.

\subsection{Slope of terrain}

The wind farm site and the surrounding region should be plain to provide accessibility for installation and maintenance of wind turbines.

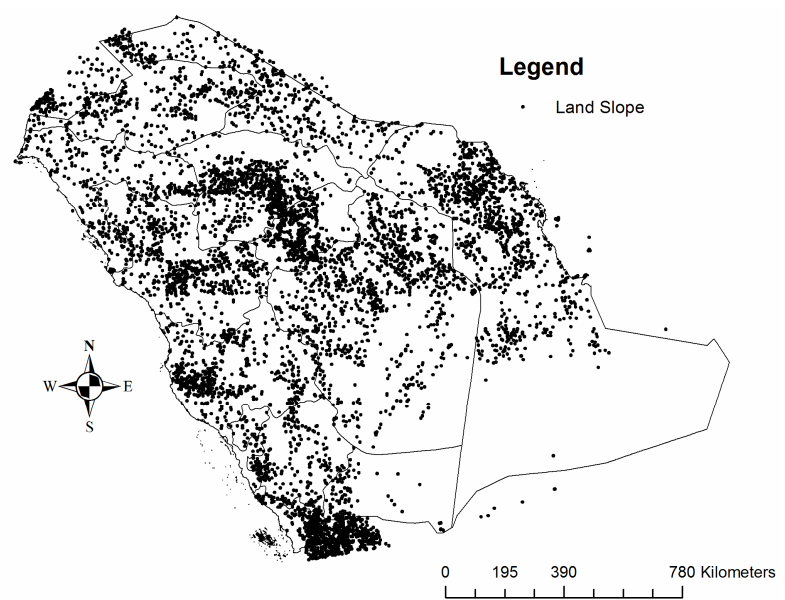

Figure 11. The areas with a slope greater than $15 \%$. 
Moreover, the wind may also be blocked by the terrain from the high altitude directions. In reviewed studies, the allowed maximum slope threshold range is considered from $10 \%$ [10] to $30 \%$ [35]. In a few studies, $[12,29,36]$ the criterion of the slope is completely neglected. The terrain slope map used in the present study is shown in Figure 11.

\section{THE METHODOLOGY OF SITE SELECTION}

All the criteria identified and discussed in the previous section are assessed simultaneously by MCDM analysis using ArcMap 10.7, 2019, the main component of ESRI's GIS software.

\subsection{Multi-criteria decision making (MCDM) of terrain}

MCDM is a method of making intricate decisions by considering the assessment of numerous variables as input criteria [21]. The identification of relevant criteria that effects site suitability is a critical step in this process. The criteria are sometimes assigned by suitable weighted classes or categories, which are then symbolized on the map layer showing the suitable areas for those criteria.

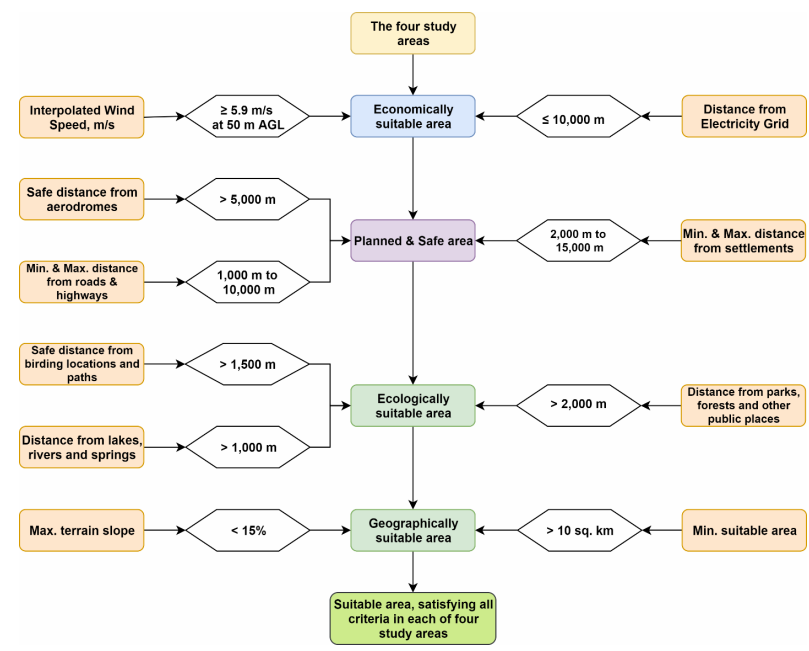

Figure 12. The conceptual model of the site suitability analysis.

The several layers, each representing identified classed criteria are superimposed over each other to create a suitability map from which the user can identify ideal areas and continue with a more detailed investigation of those sites. The selected criteria with the applied restrictions are detailed in the methodological framework illustrated in Figure 12.

\subsection{Restrictions on the selected wind farm siting criteria}

All the identified criteria correspond to several constraint factors like economic, safety, planning, ecologic, and geographical as summarized in Table 3. A suitable wind farm site should satisfy all the criteria restrictions without any exceptions and must only include areas with the high wind resource corresponding to the wind speed greater than $5.8 \mathrm{~m} / \mathrm{s}$ at $50 \mathrm{~m}$ AGL, the distance from national electrical grid less than 10000 $\mathrm{m}$, at least $5000 \mathrm{~m}$ away from all aerodromes, more than $1000 \mathrm{~m}$ and less than $10000 \mathrm{~m}$ from the roads and highways, more than $2000 \mathrm{~m}$ and less than $15000 \mathrm{~m}$ from the major settlements, at least $1500 \mathrm{~m}$ from birding locations and flying paths, at least $1000 \mathrm{~m}$ from all types of water bodies and waterways, at least 2000 $\mathrm{m}$ from parks, forests, and other public places, with a terrain less than $15 \%$ slope, and finally should have at least $10 \mathrm{~km}^{2}$ of area. As shown in the conceptual model of the site suitability analysis (Figure 12), after the application of restrictions on economical, planned, safe, ecological, and geographical criteria the suitability map is generated.

Table 3. Criteria restrictions for the location of the wind farm.

\begin{tabular}{|l|l|l|}
\hline Criteria & Restriction & Consideration \\
\hline High mean wind speed & $>5.8 \mathrm{~m} / \mathrm{s}$ & Economic \\
\hline Proximity to national grid & $<10000 \mathrm{~m}$ & Economic \\
\hline $\begin{array}{l}\text { Safe distance away from } \\
\text { aerodromes }\end{array}$ & $>5000 \mathrm{~m}$ & $\begin{array}{l}\text { Safety/Planni } \\
\text { ng }\end{array}$ \\
\hline $\begin{array}{l}\text { Distance from } \\
\text { roads/highways }\end{array}$ & 1000 to $10000 \mathrm{~m}$ & Planning \\
\hline Distance from settlements & 2000 to $15000 \mathrm{~m}$ & Planning \\
\hline $\begin{array}{l}\text { Safe distance from birding } \\
\text { locations and flying paths }\end{array}$ & $>1500 \mathrm{~m}$ & $\begin{array}{l}\text { Safety/Ecolog } \\
\text { ic }\end{array}$ \\
\hline $\begin{array}{l}\text { Distance from lakes, rivers, } \\
\text { and springs }\end{array}$ & $>1000 \mathrm{~m}$ & Ecologic \\
\hline $\begin{array}{l}\text { Distance from parks, forests } \\
\text { and public places }\end{array}$ & $>2000 \mathrm{~m}$ & Ecologic \\
\hline Terrain slope & $<15 \%$ & Geographic \\
\hline $\begin{array}{l}\text { Minimum suitable } \\
\text { continuous area }\end{array}$ & $>10 \mathrm{~km}^{2}$ & $\begin{array}{l}\text { Geographic/pl } \\
\text { anning }\end{array}$ \\
\hline
\end{tabular}

\section{RESULTS AND DISCUSSION}

Understandably, the foremost criterion in this site selection analysis is the wind resource in the region. An accurate wind map is very essential for planning a wind farm.

\subsection{The wind map of Saudi Arabia}

To identify areas with high wind resource, the hourly averaged wind data of 46 weather stations from 1980 to 2019 is used to construct a recent and accurate wind map of Saudi Arabia. Firstly, the inverse distance weighted, IDW is used to predict the wind speed between the weather stations and construct the wind map. This spatial interpolation technique converts the point wind data into a raster area format. This technique determines the cell values of missing data using a linear weighted combination of a set of sample points. The weight is a function of inverse distance. The surface being interpolated should be a variable dependent on the location. This interpolated wind data is then reclassified into 9 classes as shown in the wind map in Figure 13. This interpolated wind speed at $50 \mathrm{~m} \mathrm{AGL}$, is found to be ranging from 3.7 to $6.4 \mathrm{~m} / \mathrm{s}$. The last two classes ranging from 5.8 to $6.4 \mathrm{~m} / \mathrm{s}$ are considered to be excellent and are considered suitable for the wind farm site. It can be observed that the eastern and the central region is abundant in wind resources and a few small areas in the northern border and southern-north coastal region. In general, the southern coastal area is lacking in 
good wind resources and corresponds to wind classes 1 to 5 (wind speed less than $5 \mathrm{~m} / \mathrm{s}$ at $50 \mathrm{~m} \mathrm{AGL).} \mathrm{The}$ reclassified wind map (Figure 13) is the first of its kind as it is based on long term (39 years of historical, accurate, and latest wind speed data) obtained from 46 stations, spread over the entire country. Different layers of suitable and unsuitable criteria used in this study are shown schematically in Figs. 14 to 21 . The study is performed using ArcMap 10.7, 2019, the main component of ESRI's ArcGIS suite of geospatial processing programs.

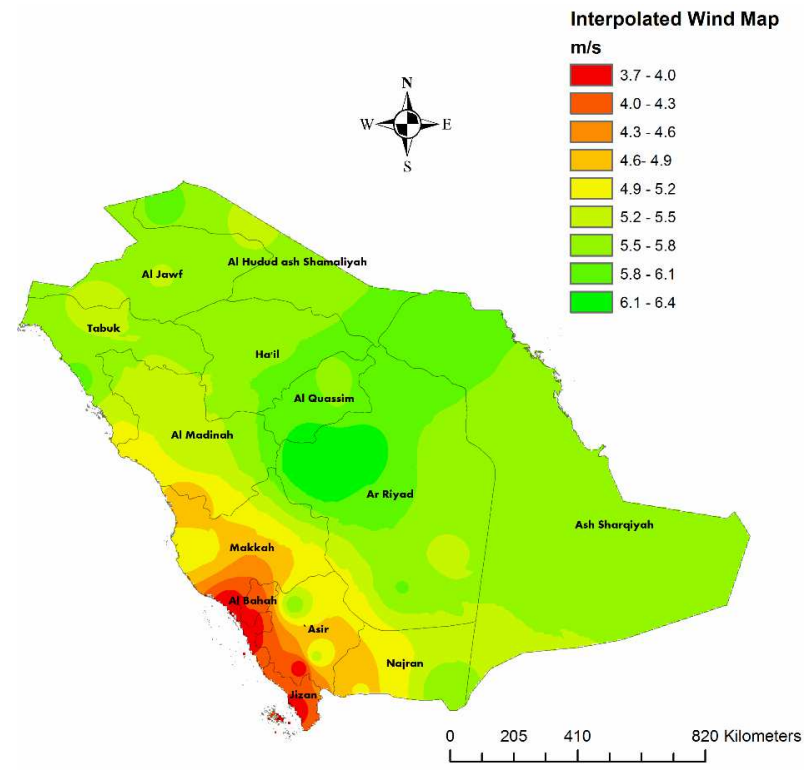

Figure 13. The wind map of Saudi Arabia.

\subsection{The maps with criteria restrictions}

The areas with wind resources corresponding to classes 8 and 9 (wind speed $>5.8 \mathrm{~m} / \mathrm{s}$ at $50 \mathrm{~m} \mathrm{AGL}$ ) are depicted on the density map in Figure 14. All the areas with wind speed less than $5.8 \mathrm{~m} / \mathrm{s}$ are removed using the 'erase' function of the program from the wind map. It can be observed that the eastern and central regions are most suitable along with few small areas in the north, west, and southern regions. All the areas which are 10 $000 \mathrm{~m}$ or farther from the national electric grid are considered unsuitable and removed from the map of existing, ongoing, and planned national electricity grid (Figure 15). It is observed that the regions with the dense desert in the eastern province are not connected to the grid and are thinly populated and therefore not considered for wind farm development. The area within $5000 \mathrm{~m}$ of aerodromes, military, passenger, and cargo airports is considered unsuitable and erased from the map shown in Figure 16. The shapefiles of roads and highways are combined in one map using the merge function in ArcMap (Figure 17). Additionally, all the areas which are away $(>10000 \mathrm{~m}$ and $<1000 \mathrm{~m}$ ) from highways and roads are not included in the analysis and excluded from the map shown in Figure 17. It is observed that the areas in the central and the southwestern regions are well connected with roads and highways and seem to be more suitable under this criterion. A prospective wind farm should be closer to the population to efficiently serve the community, whe- reas it should be not too close for ecological reasons. In this study, the areas more than $15000 \mathrm{~m}$ and less than 2 $000 \mathrm{~m}$ away from major settlements are considered unsuitable and depicted in the map (Figure 18).

In general, the land of Saudi Arabia is arid and scarce in water, therefore, the migrating birds mostly fly along the Arabian Gulf in the east. Most of the important bird areas are located along this coast. In this analysis, bird breeding, feeding, and resting locations which are less than $1500 \mathrm{~m}$ away from these locations are considered to be dangerous for birds and hence unsuitable (Figure 19). The areas nearby waterbodies are also considered unsuitable ecologically. Additionally, a buffer distance of $1000 \mathrm{~m}$ from springs, perennial, and nonperennial rivers and lakes is considered unsuitable and hence excluded from the map (Figure 20). Also, all the areas nearby; around $2000 \mathrm{~m}$; of forests, parks, and other public places are unsuitable ecologically and hence are removed from the map (Figure 21). Finally, the areas with a slope of more than $15 \%$ are not included in the suitability map because the construction of wind farms is not possible on steep slopes and it also blocks wind from the high altitude directions. The areas which are found suitable for wind farm construction but have area $<10$ $\mathrm{km}^{2}$ are also excluded from the suitability map.

\subsection{The final suitability maps of the four regions}

The site suitability analysis is performed separately for the four identified regions, as shown earlier in Figure 2. The names and areas of the thirteen provinces in each of the four selected regions and the suitable area for wind farm development within the province and selected region are presented in Table 4 . The percentages of suitable land areas are also shown in column 8 of Table 4. The wind farm site suitability maps for these regions are shown in Figs. 22 to 25.

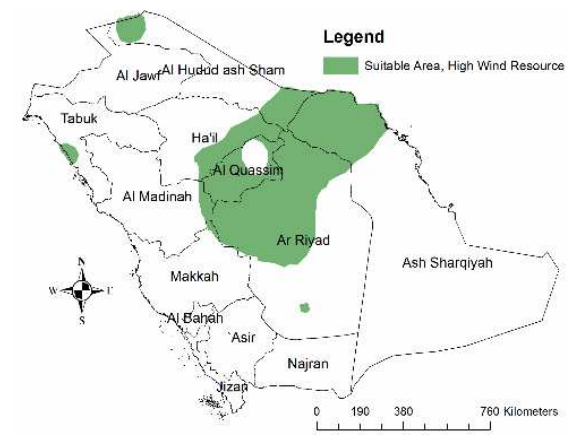

Figure 14. The suitable area based on wind resources

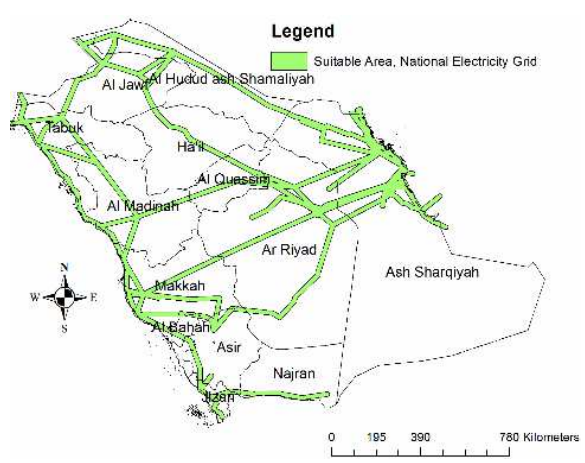

Figure 15. The suitable area based on Proximity to the National Electricity Grid 
Table 4. Area suitable for wind farm development

\begin{tabular}{|c|c|c|c|c|c|c|c|c|}
\hline $\begin{array}{l}\text { S. } \\
\text { No }\end{array}$ & $\begin{array}{l}\text { The } \\
\text { selected } \\
\text { regions }\end{array}$ & & Provinces & $\begin{array}{l}\text { Area, } \\
\mathrm{km}^{2}\end{array}$ & $\begin{array}{l}\text { Total } \\
\text { area } \\
\mathrm{km}^{2}\end{array}$ & $\begin{array}{c}\text { Suitable } \\
\text { area } \\
\mathrm{km}^{2}\end{array}$ & $\begin{array}{c}\text { Total } \\
\text { suitable } \\
\text { area } \\
\mathrm{km}^{2}\end{array}$ & $\begin{array}{c}\text { Percentage } \\
\text { of suitable } \\
\text { area, } \%\end{array}$ \\
\hline \multirow{3}{*}{1.} & \multirow{3}{*}{$\begin{array}{c}\text { The } \\
\text { Northern } \\
\text { Area }\end{array}$} & 1. & $\begin{array}{c}\text { Al Hudud } \\
\text { ash } \\
\text { Shamaliyah } \\
\end{array}$ & 117687 & \multirow{3}{*}{336191} & 1385.37 & \multirow{3}{*}{1452.4} & \multirow{3}{*}{0.43} \\
\hline & & 2. & Al Jawf & 117979 & & - & & \\
\hline & & 3. & Tabuk & 100525 & & 67.03 & & \\
\hline \multirow{3}{*}{2.} & \multirow{3}{*}{$\begin{array}{c}\text { The } \\
\text { Central } \\
\text { Area }\end{array}$} & 1. & Ar Riyad & 377605 & \multirow{3}{*}{553575} & 5664.21 & \multirow{3}{*}{8576.41} & \multirow{3}{*}{1.54} \\
\hline & & 2. & $\begin{array}{c}\mathrm{Al} \\
\text { Quassim } \\
\end{array}$ & 54449 & & 2582.24 & & \\
\hline & & 3. & Hail & 121521 & & 329.95 & & \\
\hline 3. & $\begin{array}{l}\text { The } \\
\text { Eastern } \\
\text { Area }\end{array}$ & 1. & $\begin{array}{c}\text { Ash } \\
\text { Sharqiyah }\end{array}$ & 553109 & 553109 & 3290.99 & 3290.99 & 0.59 \\
\hline \multirow{6}{*}{4.} & \multirow{6}{*}{$\begin{array}{c}\text { The } \\
\text { Southern } \\
\text { Area }\end{array}$} & 1. & $\begin{array}{c}\mathrm{Al} \\
\text { Madinah }\end{array}$ & 145199 & \multirow{6}{*}{475271} & 201.80 & \multirow{6}{*}{201.80} & \multirow{6}{*}{0.04} \\
\hline & & 2. & Makkah & 138410 & & - & & \\
\hline & & 3. & Al Bahah & 10344 & & - & & \\
\hline & & 4. & Asir & 77239 & & - & & \\
\hline & & 5. & Najran & 88266 & & - & & \\
\hline & & 6. & Jizan & 15813 & & - & & \\
\hline
\end{tabular}

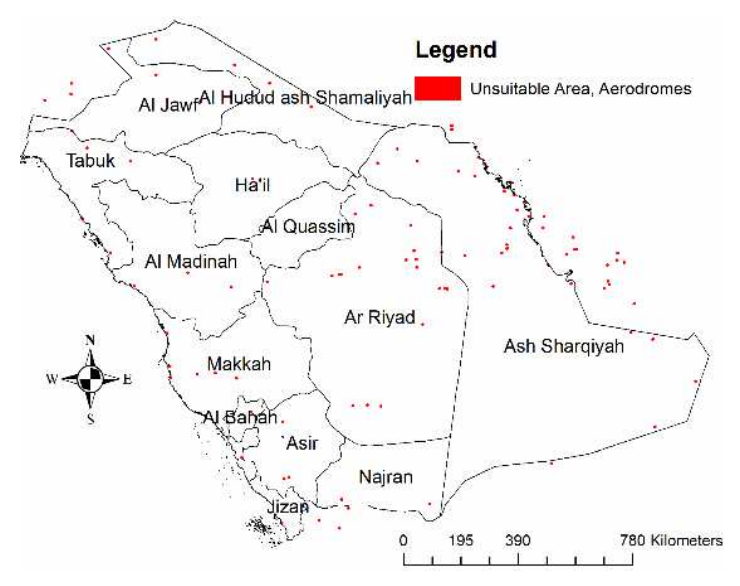

Figure 16. The suitable area based on the safe distance from all aerodromes

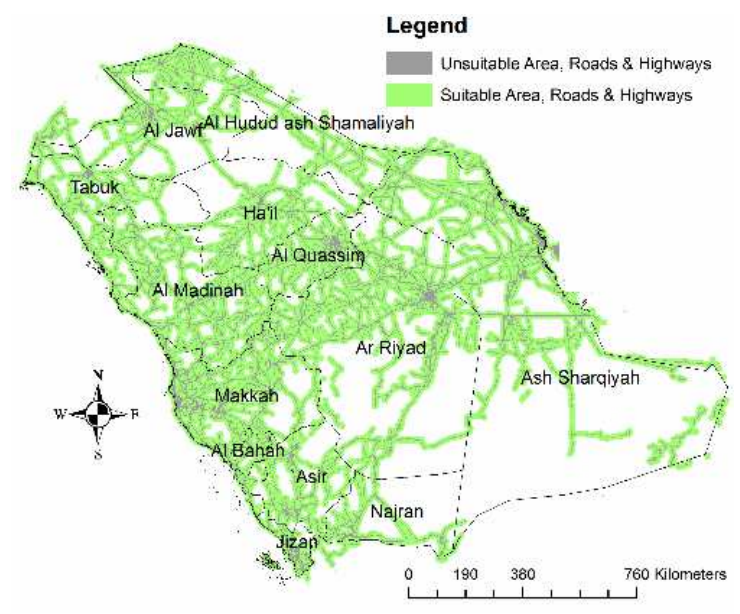

Figure 17. The suitable and unsuitable area based on distance from roads and highways

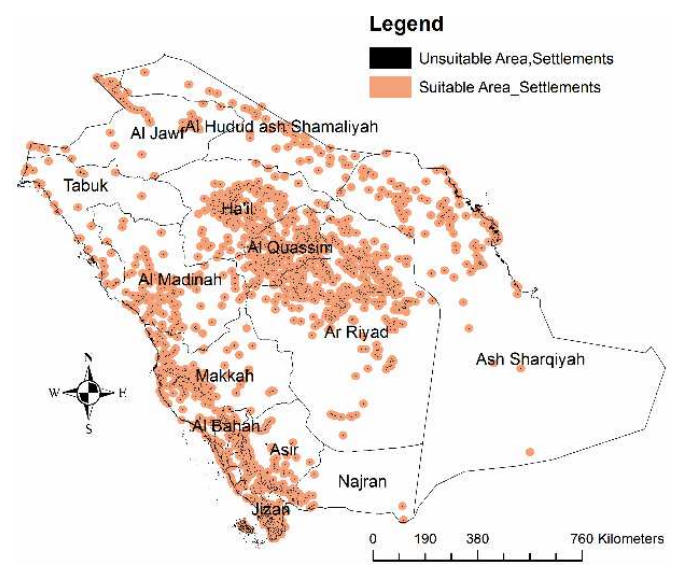

Figure 18. The suitable and unsuitable area based on distance from major settlements

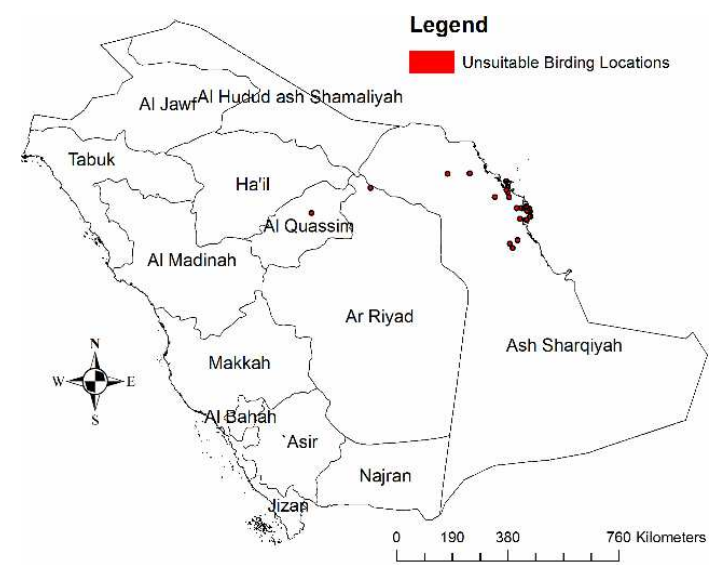

Figure 19. The unsuitable area based on distance from birding locations. 


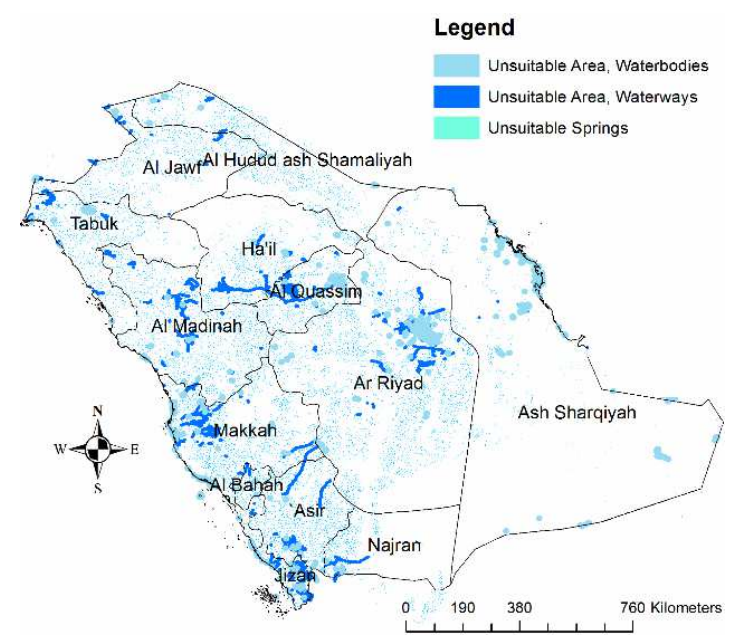

Figure 20. The unsuitable area based on distance from waterbodies, waterways, and springs.

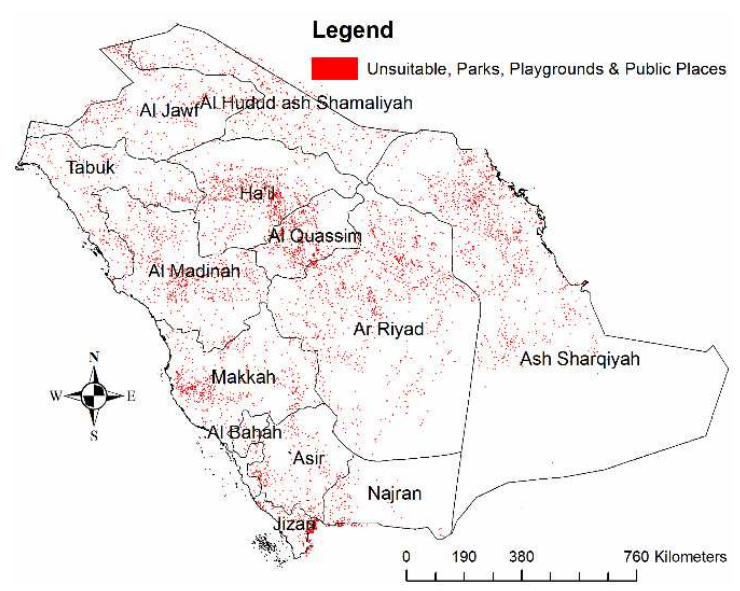

Figure 21. The unsuitable area based on distance from parks, playgrounds, and other public places.

\subsubsection{The Northern Area}

In the northern region, three wind farm sites are identified that satisfy all the criteria listed in Table 4 . Site 1 is located in Turaif, near the Jordanian border, and site 2 in the middle of the northern Iraqi border near Hafr Al Batin, Al Hudud ash Shamaliyah province. Site 3 is located in Tabuk province, on the Red Sea coast (Figure 22). There is no suitable wind farm site in Al Jawf province, as shown in Table 4. A total of $1452 \mathrm{~km}^{2}$ of the area is suitable, about $0.43 \%$ of the total selected area in the Northern Province.

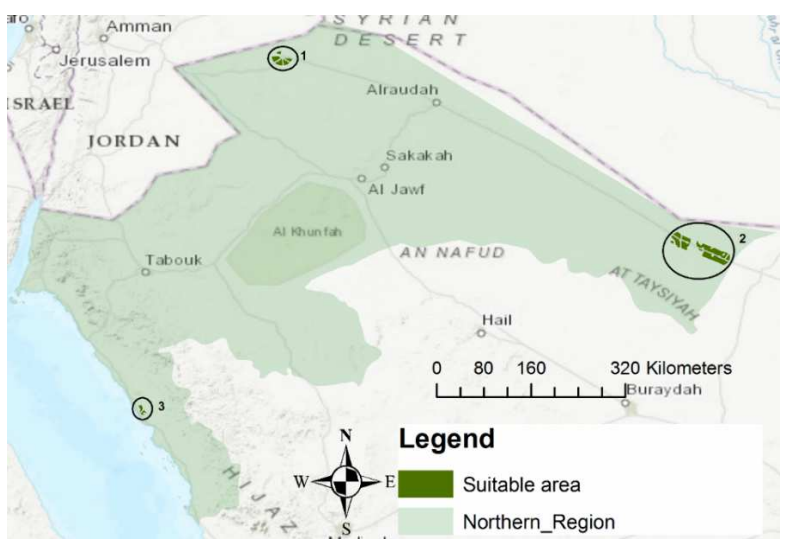

Figure 22. The windfarm site suitability map of the northern region

\subsubsection{The Central Area}

In Central Province, the more suitable area is found compared to other regions due to good wind resources and required proximity of roads for ease of equipment transport and grid for wind power dispatch from the wind farms. Most of the suitable sites are seen in Riyadh and Hail province and a few in Al Quassim as well. A total of $8576.41 \mathrm{~km}^{2}$ of the area is found to be suitable for wind farm development which accounts for about $1.54 \%$ of the total regional area (Figure 23). This percentage is highest compared to the other three regions.

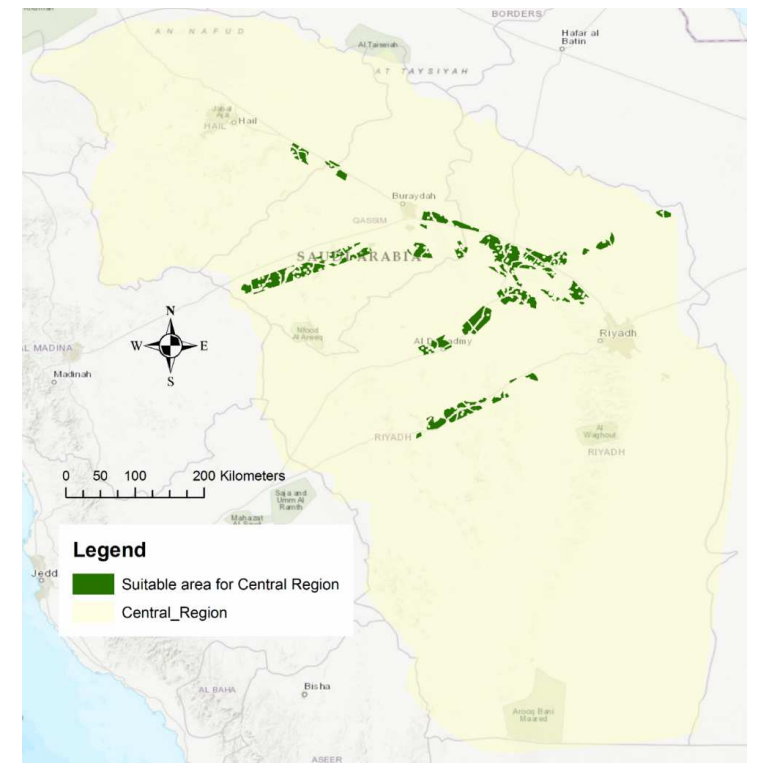

Figure 23. The windfarm site suitability map of the central region.

\subsubsection{The Eastern Area}

The eastern region is comprised of one large province, Ash Sharqiyah. Most of the eastern region is found unsuitable for wind farm development as shown in Figure 24.

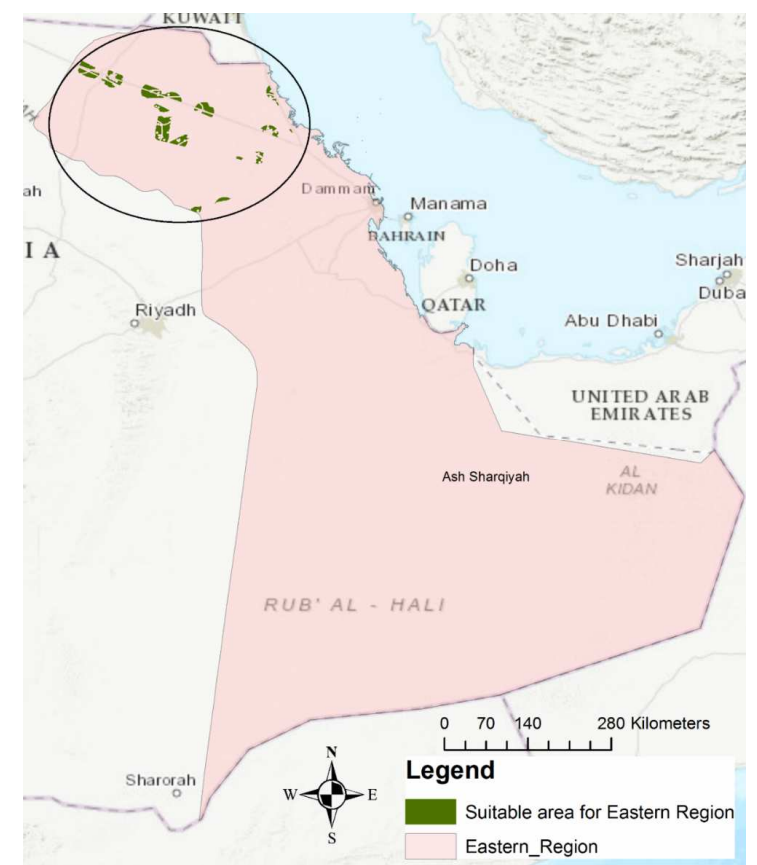

Figure 24. The windfarm site suitability map of the eastern region. 
This province holds the largest unpopulated desert in the world, Rub Al Khali. There is no electric grid and has limited road connectivity. In this region, suitable sites for wind farm development are observed between Dammam and Hafr Al Batin city. A total of $3291 \mathrm{~km}^{2}$ of the area is found to be suitable for wind farm development i.e. about $0.59 \%$ of the total area of the Eastern Province.

\subsubsection{The Southern Area}

The southern area holds six provinces and has limited suitable areas for wind farm development. These suitable sites are concentrated around the Madinah region while other provinces do not have any potential windy areas (Figure 25). A total of $201.8 \mathrm{~km}^{2}$ of the area is found to be suitable for wind farm development which accounts for only $0.04 \%$ of the total regional area. This area percentage share is the lowest compared to the other three regions.

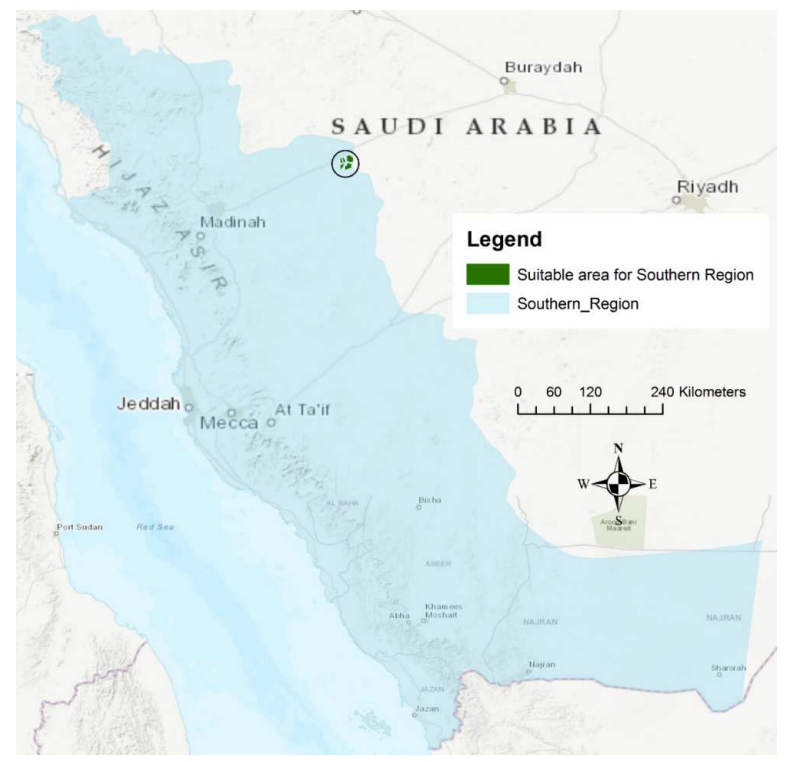

Figure 25. The windfarm site suitability map of the southern region.

\section{CONCLUSION}

In this study, a GIS-based multi-criteria decision-making model is developed for suitable wind farm site selection considering various ecological, environmental, and socioeconomic criteria and applied to Saudi Arabia. Ministry of Energy has set an initial target of installing $9.5 \mathrm{GW}$ of renewable energy by 2023 [37]. This target accounts for about $15 \%$ of the total energy consumption. This study will help in identifying the profitable potential sites for wind power deployment to partially achieve this target explicitly from the point of view of proper site selection and maximum harnessing of wind energy.

For this purpose, long-term historical hourly mean wind speed data were obtained for 46 stations throughout the country for 40 years between 1980 and 2019. A spatial interpolation technique is used to estimate the wind speed at some locations where direct data was not available to build an accurate wind map of the country. This wind map is used as a reference for large scale wind energy installations as it gives an estimate of the wind speed where physical meteorological stations do not exist.
A list of all criteria that may have a direct or indirect impact on the siting of the wind farm is identified from the literature. All the criteria are given equal weightage in the analysis. However, with noncompliance with even a single criterion condition, the associated complete area is considered unsuitable.

The site suitability analysis is performed separately for the four identified regions, the northern, the eastern, the central and the southern. In the northern region, three wind farm sites are identified at Turaif, near the Jordanian border, in the middle of the northern Iraqi border near Hafr Al Batin, and in the Tabuk province, on the Red Sea coast. A total of $1452 \mathrm{~km}^{2}$ of the area is suitable which is about $0.43 \%$ of the total selected northern area. The central area is found to have a more suitable area compared to other regions mainly due to good wind resources, roads, and grid connectivity. Most of the suitable sites are found in Riyadh and Hail province and a few in $\mathrm{Al}$ Quassim too. A total of $8576.41 \mathrm{~km}^{2}$ of the area is found to be suitable for wind farm development, pertaining to about $1.54 \%$ of the total regional area. In the eastern region, suitable sites are located between Dammam and Hafr Al Batin city. A total of $3291 \mathrm{~km}^{2}$ of the area is found to be suitable for wind farm realization, i.e. about $0.59 \%$ of the total eastern area. The southern region has the least potential area for wind power plant development. A total of 201.8 $\mathrm{km}^{2}$ of the area is found to be suitable for wind farm development which is around $0.04 \%$ of the total regional area. In a similar study for Saudi Arabia, the entire region was ranked using criteria weighted overlay method but with wind data from 29 weather stations only. A few relevant criteria like safe distance from birding locations and flying paths, buffer distance from lakes, rivers, springs, parks, forests and public places and terrain slope were neglected [9].

The selection of the optimum wind turbines and the design layout for the suitable wind farm sites identified in this study can be considered as future work. The selection of an optimum wind turbine is a challenging task [38] and requires consideration of various factors in the decision-making process $[9,39-46]$.

\section{ACKNOWLEDGMENT}

The authors would like to acknowledge the support provided by the deanship of scientific research (DSR) at King Fahd University of Petroleum \& Minerals (KFUPM) for funding this work through grant number SB181005.

\section{REFERENCES}

[1] U. S. E. I. Administration, "International Energy Outlook 2019," 2019.

[2] T. E. Amin, G. Roghayeh, R. Fatemeh, and P. Fatollah, "Evaluation of nanoparticle shape effect on a nanofluid based flat-plate solar collector efficiency," Energy Explor. Exploit., 2015.

[3] J. T. Dellosa, "Potential effect and analysis of high residential solar photovoltaic (PV) systems penetration to an electric distribution utility (DU)," Int. J. Renew. Energy Dev., 2016. 
[4] Rehman, S. \& Natarajan, N. \& Mohandes, Mohd \& Alam, Mahbub. (2020). Latitudinal wind power resource assessment along coastal areas of Tamil Nadu, India. FME Transactions. 48. 566-575. 10.5937/fme2003566R.

[5] Y. Noorollahi, H. Yousefi, and M. Mohammadi, "Multi-criteria decision support system for wind farm site selection using GIS," Sustain. ENERGY Technol. ASSESSMENTS, vol. 13, pp. 38-50, 2016.

[6] G. Wind and E. Council, "NAME HERE REPORT 2018 GWEC | GLOBAL WIND REPORT 2018," no. April, 2019.

[7] P. Technology, "Dumat Al Jandal Wind Farm." [Online]. Available: https://www.powertechnology.com/projects/dumat-al-jandal-windfarm. [Accessed: 17-Feb-2020].

[8] Ž. Stevi, "SS symmetry Application of MCDM Methods in Sustainability Engineering: A Literature Review 2008 - 2018," 2018.

[9] M. A. Baseer, S. Rehman, J. P. Meyer, and M. M. Alam, "GIS-based site suitability analysis for wind farm development in Saudi Arabia," Energy, 2017.

[10] S. M. J. Baban and T. Parry, "Developing and applying a GIS-assisted approach to locating wind farms in the UK," Renew. Energy, 2001.

[11]W. Krewitt and J. Nitsch, "The potential for electricity generation from on-shore wind energy under the constraints of nature conservation: A case study for two regions in Germany," Renew. Energy, 2003.

[12] H. S. Hansen, "GIS-based multi-criteria analysis of wind farm development," in ScanGIS 2005 Proceedings of the 10th Scandinavian Research Conference on Geographical Information Sciences, 2005.

[13] M. Argin, V. Yerci, N. Erdogan, S. Kucuksari, and U. Cali, "Exploring the offshore wind energy potential of Turkey based on multi-criteria site selection," Energy Strateg. Rev., vol. 23, no. March 2018, pp. 33-46, 2019.

[14]Z. Li, "Study of site suitability assessment of regional wind resources development based on multi-criteria decision," Clean Technol. Environ. Policy, vol. 20, no. 6, pp. 1147-1166, 2018.

[15] K. Azad, M. Rasul, P. Halder, and J. Sutariya, "Assessment of wind energy prospect by weibull distribution for prospective wind sites in Australia," in Energy Procedia, 2019.

[16]D. Latinopoulos and K. Kechagia, "A GIS-based multi-criteria evaluation for wind farm site selection. A regional scale application in Greece," Renew. Energy, 2015.

[17] "General Authority of Statistics, Saudi Census," Statistical Yearbook, 2015. [Online]. Available: https://www.stats.gov.sa/en/4025. [Accessed: 17Feb-2020].

[18] The Editors of Encyclopaedia Britannica, "Encyclopaedia Britannica," Rub' al-Khali. [Online]. Available: https://www.britannica.com/place/Rub-
al-Khali.

[19] "Saudi Industrial Development Fund, SIDF," 2019. [Online].

Available: https://www.sidf.gov.sa/en/Pages/default.aspx. [Accessed: 17-Feb-2020].

[20]"KACARE," 2020. [Online]. Available: https://www.kacare.gov.sa/ar/pages/default.aspx. [Accessed: 17-Feb-2020].

[21] R. Van Haaren and V. Fthenakis, "GIS-based wind farm site selection using spatial multi-criteria analysis (SMCA): Evaluating the case for New York State," Renewable and Sustainable Energy Reviews. 2011.

[22]B. Sliz-Szkliniarz and J. Vogt, "GIS-based approach for the evaluation of wind energy potential: A case study for the KujawskoPomorskie Voivodeship," Renewable and Sustainable Energy Reviews. 2011.

[23] S. H. Siyal, U. Mörtberg, D. Mentis, M. Welsch, I. Babelon, and M. Howells, "Wind energy assessment considering geographic and environmental restrictions in Sweden: A GIS-based approach," Energy, 2015.

[24] "Global modeling \& assimilation office," National Aeronautics and Space Administration, NASA, 2020. [Online]. Available: https://gmao.gsfc.nasa.gov/reanalysis/MERRA2/data_access/. [Accessed: 17-Feb-2020].

[25] S. Rehman, M. Shoaib, I. Siddiqui, F. Ahmed, M. Tanveer, and S. Jilani, "Effect of Wind Shear Coefficient for the Vertical Extrapolation of Wind Speed Data and its Impact on the Viability of Wind Energy Project," J. Basic Appl. Sci., 2015.

[26]B. Peros, I. Boko, and V. Divic, "Wind shear characteristics of local winds," in 7th Asia-Pacific Conference on Wind Engineering, APCWE-VII, 2009.

[27] M. R. Patel, Wind and Solar Power Systems. 2005.

[28] M. S. Islam, M. Mohandes, and S. Rehman, "Vertical extrapolation of wind speed using artificial neural network hybrid system," Neural Comput. Appl., 2017.

[29] N. Y. Aydin, E. Kentel, and S. Duzgun, "GIS-based environmental assessment of wind energy systems for spatial planning: A case study from Western Turkey," Renewable and Sustainable Energy Reviews. 2010.

[30] K. Q. Nguyen, "Wind energy in Vietnam: Resource assessment, development status and future implications," Energy Policy, 2007.

[31] SEC, "Saudi Electricity Co. Annual Report," 2019.

[32] EarthWorks, "Stanford Libraries," ESRI, 2020. .

[33] J. Babbington, "Birds of Saudi Arabia." [Online]. Available: https://www.birdsofsaudiarabia.com/p/birdinglocations.html. [Accessed: 10-Feb-2020].

[34]M. Shobrak, "Bird flyways and stopover conservation sites in the arabian peninsula," Zool. Middle East, 2011. 
[35] L. I. Tegou, H. Polatidis, D. A. Haralambopoulos, "Environmental management framework for wind farm siting: Methodology and case study," $J$. Environ. Manage., 2010.

[36]F. Rahman, S. Rehman, and M. A. Abdul-Majeed, "Overview of energy storage systems for storing electricity from renewable energy sources in Saudi Arabia," Renewable and Sustainable Energy Reviews. 2012.

[37] "Vision 2030," 2019.

[38] B. Rašuo, M. Dinulović, A. Veg, A. Grbović, A. Bengin, "Harmonization of new wind turbine rotor blades development process: A review," Renew. Sustain. Energy Rev., vol. 39, pp. 874-882, 2014.

[39] S. Rehman, S. A. Khan, "Fuzzy logic based multicriteria wind turbine selection strategy - A case study of Qassim, Saudi Arabia," Energies, 2016.

[40] M. M. Rafique, S. Rehman, M. M. Alam, L. M. Alhems, "Feasibility of a $100 \mathrm{MW}$ installed capacity wind farm for different climatic conditions," Energies, 2018.

[41] S. Rehman and S. A., "Multi-Criteria Wind Turbine Selection using Weighted Sum Approach," Int. J. Adv. Comput. Sci. Appl., 2017.

[42] S. Rehman, M. M. Rafique, M. M. Alam, and L. M. Alhems, "Vertical axis wind turbine types, efficiencies, and structural stability - A Review," Wind and Structures, An International Journal. 2019.

[43] M. A. Baseer, J. P. Meyer, S. Rehman, M. M. Alam, "Wind power characteristics of seven data collection sites in Jubail, Saudi Arabia using Weibull parameters," Renew. Energy, vol. 102, 2017.

[44] S. Rehman, S. S. Ali, and S. A. Khan, "Wind Farm Layout Design Using Cuckoo Search Algorithms," Appl. Artif. Intell., 2018.

[45]B. P. Rašuo, A. Bengin, "Optimization of wind farm layout," FME Trans., vol. 38, no. 3, pp. 107114, 2010.

[46] B. Rašuo, A. Bengin, A. Veg, "On Aerodynamic Optimization of Wind Farm Layout," Pamm, vol. 10, no. 1, pp. 539-540, 2010.

[47] P. Díaz-Cuevas, "GIS-based methodology for evaluating the wind-energy potential of territories: A case study from Andalusia (Spain)," Energies, 2018.

\section{NOMENCLATURE \\ GIS Geographic Information System \\ MCDM Multi-Criteria Decision Making \\ IDW Inverse Distance Weighted \\ AGL Above Ground Level \\ WS Wind Speed \\ $\mathrm{V}_{1} \quad$ Average Wind Speed at Height 1}

\section{Superscripts}

n Wind Shear Coefficient

\section{ВИШЕКРИТЕРИЈУМСКА МЕТОДОЛОГИЈА \\ ИЗБОРА ЛОКАЦИЈЕ ВЕТРОПАРКА \\ БАЗИРАНА НА ГЕОГРАФСКОМ \\ ИНФОРМАЦИОНОМ СИСТЕМУ}

\section{С. Рехман, М.А. Басер, Л.М. Алхемс}

Сматра се да ће глобална потражња за енергијом, у односу на тренутну ситуацију, порасти за 50\% до 2050. године. Очекује се да ће пројектоване потребе за електричном енергијом у Саудијској Арабији бити веће од 120 гигавата годишње до 2032. Саудијска влада је поставила циљ да ветропаркови произведу 9,5 гивавата до 2023. У раду се користи техника просторне интерполације за израду прецизне мапе ветрова за целу земљу.

Развијен је вишекритеријумски модел одлучивања за избор погодних локација за изградњу ветропаркова, који укључује еколошке, безбедне по околину и социо-економске критеријуме. Сви кретиријуми имају подједнаку тежину код модела. Према томе, уколико није задовољен један од наведених критеријума таква локација се сматра непогодном. У студији случаја овај модел је примењен на четири региона који покривају целу Саудијску Арабију. У северном делу земље одређене су три локације. Централна зона има погодније локације у поређењу са осталим регионима, јер има добре ресурсе ветра, путну и координатну мрежу. У источном делу земље одговарајуће локације се налазе између Дамама и Хафр АлБатина. Јужни регион има најмање погодне локације за експлоатацију енергије ветра, једино у близини провинције Мадина. 